\title{
Effects of anthropogenic activities on water quality, and phosphate and nitrates in the sediment of River Ogun at Ijaye, Isabo and Oke-sokori, Ogun State
}

\author{
Festus Idowu ADEOSUN
}

Department of Aquaculture and Fisheries Management, Federal University of Agriculture, Abeokuta, PMB 2240, Ogun State, Nigeria. E-mail: adeosunfi@yahoo.com; Tel : +2348038057564.

\begin{abstract}
Water pollution is an issue of concern over the years in many countries. This study investigated the effect of human activities on the water and soil sediments of River Ogun at Ijaye, Isabo and Sokori from June to November 2017. The physico-chemical parameters of the water in all the three locations were measured and recorded twice monthly using standard methods. Determination of phosphate and nitrate in the soil was carried out. One-way analysis of variance was employed for data analyses, and means were differentiated using Duncan multiple range tests. No significant difference $(\mathrm{p}>0.05)$ in the mean of all the parameters tested for in all three locations. Monthly range in temperature was within $24.75{ }^{\circ} \mathrm{C}-27.55^{\circ} \mathrm{C}$. Highest mean electrical conductivity $(531.00 \mu \mathrm{s} / \mathrm{cm})$, dissolved oxygen $(7.56 \mathrm{mg} / \mathrm{l})$ and alkalinity $(2.80 \mathrm{mg} / \mathrm{l})$ were recorded at Location C (Oke-Sokori). High positive correlation was obtained between water phosphate and water nitrate, soil phosphate, soil nitrate and between $\mathrm{pH}$ and dissolve oxygen, electrical conductivity. It was concluded that the water from all three locations are still within the recommended reference for fish. There is need to constantly monitor the water at these locations as levels of some of the parameters have exceeded the permissible limit for fish.
\end{abstract}

(C) 2019 International Formulae Group. All rights reserved

Keywords: Dissolve oxygen, Electrical conductivity, River Ogun, sediment, water quality parameter.

\section{INTRODUCTION}

Rivers and lakes are a part of human history and have been largely utilized by mankind with time, such that they have been greatly affected by human activities leaving few or non in its 'natural' state. Rivers around urban areas are characterized with pollution and water quality problems due basically to careless disposal of waste from industrial effluents and other point and non point source into rivers (Chindah et al., 2004; Emongore et al., 2005). Ever increasing world population, soil erosion, intensive deforestation, urbanization, hydrological change, and inadequate water use have caused major reduction in the river water quality. This situation in the urban areas continues to increase due to careless disposal of industrial waste and defective drainage system.

Human activities has greatly impacted on suspended sediment loads in major rivers of the world and have been largely studied including in Africa and Nigeria (Isik et al., 2008; Ayobahan et al., 2014; Abdulraheem et 
al., 2017; Owuor et al., 2018). Abdulraheem et al., (2017) reported that there are heavy concentrations of $\mathrm{Zn}, \mathrm{Pb}$, and $\mathrm{Cu}$ beyond the acceptable limits in River Sokori which could be harmful to the fisheries resources of this water body, and the populace who rely on this water body through the food chain.

There had been significant increase in population growth and industrial activities around this water body in the recent years, and little or no information had been documented regarding the pollution state of this water body at these points. This study was therefore designed with the focus on the quality of the water and soil sediments of the River Ogun at Ijaye, Isabo and Sokori.

\section{MATERIALS AND METHODS Study area}

The study was carried out in urban areas of Abeokuta, the capital of Ogun State, Nigeria. Abeokuta is in the sub-humid tropical region of Southwestern Nigeria, and lies between latitude $7^{\circ} 5^{\prime} \mathrm{N}-7^{\circ} 20^{\prime} \mathrm{N}$ and longitude $3^{\circ} 17^{\prime} \mathrm{E}-3^{\circ} 27^{\prime} \mathrm{E}$. It has a population of 605,451 (Projected from 1991 Census of 374,043 at $3.5 \%$ growth rate). Its geographical location makes it easily accessible from Lagos, the industrial capital of Nigeria and the nation's major seaport. The city covers a geographical area of $1,256 \mathrm{~km}^{2}$, which include Abeokuta South, Abeokuta North and part of Obafemi Owode and Odeda Local Government Areas of Ogun State. The major activities in Abeokuta are trading, textile making, artisans and transportation activities. Houses in these areas are densely populated with about six to twenty persons per house.

\section{Water sample collection}

Water samples for physico-chemical analysis were collected from all the locations bi-monthly from June - November 2017. The samples were then taken to a quality control laboratory immediately for physical and chemical analysis of the following parameters: Dissolved oxygen, Electrical Conductivity, $\mathrm{pH}$, Acidity, Alkalinity.

\section{Dissolved oxygen analysis}

Dissolved oxygen was analyzed for using the Winkler's method as described by Olalekan et al. (2012). Chemicals used include Manganese II sulphide $\left(\mathrm{MnSO}_{4}\right)$ solution, alkali-iodide-azide, concentrated sulphuric acid $\left(\mathrm{H}_{2} \mathrm{SO}_{4}\right)$, Sodium thiosulphate $\left(\mathrm{Na}_{2} \mathrm{~S}_{2} \mathrm{O}_{3} .5 \mathrm{H}_{2} \mathrm{O}\right)$ solution with starch solution as reagent. To the DO bottle containing the sample, $2 \mathrm{ml}$ of $\mathrm{MnSO}_{4}$ solution was added and another $2 \mathrm{ml}$ of alkali-iodide-azide solution was also added and the sample bottle was corked and thoroughly mixed. A hundred millilitre of the mixture was measured into a conical flask using a measuring cylinder and six drops of the indicator (starch solution) was added. It was then titrated with the standard $\mathrm{Na}_{2} \mathrm{~S}_{2} \mathrm{O}_{3} .5 \mathrm{H}_{2} \mathrm{O}$ in the burette until the colour change to colourless From the average titer values obtained for each station, the dissolved oxygen concentration was calculated in $\mathrm{mg} / \mathrm{l}$ using the formula

$\mathrm{O}_{2} \mathrm{mg} / \mathrm{l}=\mathrm{t} \times 101.620 \mathrm{ml}$ of water sample

Where $t=$ titer or volume of thiosulphate used.

$101.6=$ constant.

\section{Measurement of alkalinity}

Concentrated Hydrochloric acid $(\mathrm{HCl})$ was used as reagent, phenolphthalein and methyl orange as indicator. A Hundred millilitre of the sample was poured into a conical flask, 2 drops of phenolphthalein indicator was added and no colour change was observed. Two drops of methyl orange indicator was then added, and titrated against $0.2 \mathrm{M}$ concentrated $\mathrm{HCl}$ till a pink end point was observed.

\section{Phosphate in the water body}

One hundred millilitre of water sample was measured into a conical flask. $5 \mathrm{ml}$ of conditioning reagent was added to the sample. Reading was taken using 6405 UVIVis Spectrometer at $220 \mathrm{~nm}$ wavelengths (Mcneely et al., 1979).

\section{Nitrate in the water body}

One millilitre of $\mathrm{HCl}$ was put into a nitrate bottle using a pipette. Twenty-five millilitre of water sample was put inside a 
standard flask. Four millilitre of distilled water was added and reading was done using 6405 UVIVis Spectrometer at a wavelength of 220 nautical miles (Mcneely et al., 1979).

\section{Soil sediment collection}

The sediment was collected at the bank of the river in all locations by hand into a sterilized container. This was then air dried for some days and taken to the laboratory for analysis.

\section{Nitrate analysis in sediment sample}

The collected sediment samples were sieved using a $0.5 \mathrm{~mm}$ mesh sieve. Ten grams of the sieved sediment was then measured using a weighing balance and put into a sampling bottle of $130 \mathrm{ml}$. Twenty millilitre of potassium sulphate $\left(\mathrm{K}_{2} \mathrm{SO}_{4}\right)$ was also added into the sampling bottle. The mixture was kept in an orbital shaker for about 30 minutes. Mixture was filtered, and the filtrate kept in a sampling bottle. One millilitre of salicyclic acid and $10 \mathrm{ml}$ of sodium hydroxide $(\mathrm{NaOH})$ were added to the filtrate which was observed for an hour for colour change (chlorination). The readings were done using $6405 \mathrm{UV} / \mathrm{V}$ is Spectrometer with a wavelength of $220 \mathrm{~nm}$.

\section{Phosphate analysis in sediment sample.}

Five grams of sieved sediment was measured into a sampling bottle and $25 \mathrm{ml}$ of Bray solution was added. The mixture was filtered into a sampling bottle using Whattman filter paper $110 \mathrm{~mm}$ diameters. $8 \mathrm{ml}$ of filtrate was measured into another sampling bottle and $25 \mathrm{ml}$ of Bray solution was added to another disposable scintillating vials. 10 drops of phosphorus reagent $\mathrm{B}$ was added and observed for 1 hour. Afterward, 10 drops of phosphorus reagent $\mathrm{C}$ was also added. The reading was done using 6405 UVIVis Nanometer with a wavelength of $220 \mathrm{~nm}$.

\section{Data analysis}

The data collected were subjected to one-way ANOVA analysis using the general linear model of the Statistical Package Social Sciences 16.0 (SPSS 16), and the mean differentiated using Duncan's multiple range tests.

\section{RESULTS}

\section{Physico-chemical parameters}

The result of the physico-chemical parameters was presented in Tables 1, 2 and 3. The highest mean water temperature (27.75 ${ }^{\circ} \mathrm{C}$ ) and the lowest mean water temperature $\left(24.75{ }^{\circ} \mathrm{C}\right)$ were recorded at location A (Ijaye). The highest mean $\mathrm{pH}$ (7.23) was obtained in location A (Ijaye). The lowest mean water phosphate $(6.55 \mathrm{mg} / \mathrm{l})$, water nitrate $(9.14$ $\mathrm{mg} / \mathrm{l})$, soil phosphate $(7.16 \mathrm{mg} / \mathrm{kg})$ and soil nitrate $(9.91 \mathrm{mg} / \mathrm{kg})$ were recorded at Location A (Ijaye). The highest mean electrical conductivity $(531.00 \mu \mathrm{s} / \mathrm{cm})$, dissolved oxygen $(7.56 \mathrm{mg} / \mathrm{l})$ and alkalinity (2.80 $\mathrm{mg} / \mathrm{l})$ were recorded at Location $\mathrm{C}$ (Oke-Sokori). There was no significant difference $(p>0.05)$ in the mean of all the parameters tested for in all the three locations. All parameters were compared with various national and international standards (Table 4).

\section{Correlation between the water quality parameters and sediment}

Table 5 represents the correlation analysis between the water quality parameter and sediment. The correlation result showed a significant $(\mathrm{P}<0.05)$ correlation at the $95 \%$ confidence limit. Strong positive correlation was recorded between the level of phosphate in the soil and in the water as calculated ' $r$ ' was $0.967 \mathrm{mg} / \mathrm{l}$. Soil nitrate levels gave a strong positive relationship with that in the water with calculated ' $r$ ' $0.997 \mathrm{mg} / \mathrm{l}$. Soil nitrate also had a strong positive relationship with water nitrate and viz a viz. There was strong positive relationship between water $\mathrm{pH}$ and electrical conductivity and DO. Negative correlation was recorded between $\mathrm{pH}$ in water and nitrate and phosphate. 
F. I. ADEOSUN / Int. J. Biol. Chem. Sci. 13(3): 1261-1270, 2019

Table 1: Mean monthly variation of physico-chemical parameters at location A (Ijaye).

\begin{tabular}{|c|c|c|c|c|c|c|c|c|c|c|}
\hline Months & Parameters & & & & & & & & & \\
\hline & $\begin{array}{ll}\text { Air } & \text { temp } \\
\left({ }^{\circ} \mathrm{C}\right) & \end{array}$ & $\begin{array}{l}\text { Water } \\
\text { temp }\left({ }^{\circ} \mathrm{C}\right)\end{array}$ & $\mathbf{p H}$ & $\mathrm{EC}(\mu \mathrm{s} / \mathrm{cm})$ & $\begin{array}{l}\text { Alkalinity } \\
\text { (mg/l) }\end{array}$ & DO (mg/l) & $\begin{array}{l}\text { Water } \\
\text { phosphate } \\
(\mathrm{mg} / \mathrm{l})\end{array}$ & $\begin{array}{l}\text { Water nitrate } \\
(\mathrm{mg} / \mathrm{l})\end{array}$ & $\begin{array}{l}\text { Soil } \\
\text { phosphate } \\
\text { (mg/kg) }\end{array}$ & $\begin{array}{ll}\text { Soil } & \text { nitrate } \\
(\mathrm{mg} / \mathrm{kg}) & \end{array}$ \\
\hline June & 28.60 & 27.75 & 6.58 & 495.00 & 1.75 & 4.60 & 6.67 & 9.19 & 7.25 & 9.95 \\
\hline July & 28.20 & 26.75 & 6.54 & 505.00 & 1.75 & 4.51 & 6.85 & 9.15 & 7.28 & 9.91 \\
\hline August & 28.00 & 26.10 & 6.71 & 505.00 & 1.58 & 5.18 & 6.55 & 9.14 & 7.33 & 10.15 \\
\hline September & 29.70 & 25.25 & 6.72 & 496.00 & 1.60 & 6.15 & 6.71 & 9.17 & 7.30 & 10.00 \\
\hline October & 27.50 & 24.75 & 7.05 & 525.00 & 1.57 & 6.85 & 6.87 & 9.36 & 7.16 & 9.93 \\
\hline November & 27.75 & 26.15 & 7.23 & 495.00 & 1.55 & 7.20 & 7.20 & 9.37 & 7.27 & 9.91 \\
\hline
\end{tabular}

Key: Air temp- Air temperature, Water temp- water temperature, EC- Electrical conductivity, DO- Dissolve oxygen. 
F. I. ADEOSUN / Int. J. Biol. Chem. Sci. 13(3): 1261-1270, 2019

Table 2: Mean monthly variation of physico-chemical parameters at location B (Isabo).

\begin{tabular}{|c|c|c|c|c|c|c|c|c|c|c|}
\hline Monthly & & & & & & Parameters & & & & \\
\hline & $\begin{array}{ll}\text { Air } & \text { temp } \\
\left({ }^{\circ} \mathrm{C}\right) & \end{array}$ & $\begin{array}{l}\text { Water temp } \\
\left({ }^{\circ} \mathrm{C}\right)\end{array}$ & pH & $\begin{array}{l}\text { EC } \\
(\mu \mathrm{s} / \mathrm{cm})\end{array}$ & $\begin{array}{l}\text { Alkalinity } \\
\text { (mg/l) }\end{array}$ & DO (mg/l) & $\begin{array}{l}\text { Phosphate } \\
\text { in water } \\
(\mathrm{mg} / \mathrm{l})\end{array}$ & $\begin{array}{l}\text { Nitrate in } \\
\text { water } \\
(\mathrm{mg} / \mathrm{l})\end{array}$ & $\begin{array}{l}\text { Soil } \\
\text { phosphate } \\
\text { (mg/kg) }\end{array}$ & $\begin{array}{ll}\text { Soil } & \text { nitrate } \\
(\mathrm{mg} / \mathrm{kg}) & \end{array}$ \\
\hline June & 28.50 & 27.40 & 5.44 & 440.00 & 1.53 & 4.18 & 8.67 & 16.56 & 8.95 & 16.93 \\
\hline July & 28.20 & 26.70 & 5.44 & 450.00 & 1.54 & 4.45 & 8.64 & 16.56 & 9.01 & 16.94 \\
\hline August & 28.50 & 26.50 & 5.80 & 443.50 & 1.54 & 2.95 & 8.53 & 16.62 & 9.01 & 16.95 \\
\hline September & 29.40 & 25.20 & 5.81 & 457.50 & 1.57 & 5.20 & 8.63 & 16.59 & 8.95 & 16.89 \\
\hline October & 27.85 & 25.50 & 5.93 & 500.00 & 1.54 & 5.31 & 8.65 & 16.60 & 8.94 & 17.01 \\
\hline November & 28.25 & 26.00 & 6.00 & 495.00 & 1.48 & 5.55 & 8.74 & 16.62 & 8.97 & 16.99 \\
\hline
\end{tabular}

Key: Air temp- Air temperature, Water temp- water temperature, EC- Electrical conductivity, DO- Dissolve oxygen. 


\section{F. I. ADEOSUN /Int. J. Biol. Chem. Sci. 13(3): 1261-1270, 2019}

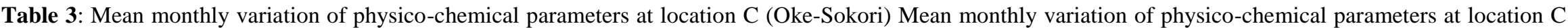
(Oke-Sokori).

\begin{tabular}{|c|c|c|c|c|c|c|c|c|c|c|}
\hline Month & Parameters & & & & & & & & & \\
\hline & Air temp $\left({ }^{\circ} \mathrm{C}\right)$ & $\begin{array}{l}\text { Water } \\
\text { temp }\left({ }^{\circ} \mathrm{C}\right)\end{array}$ & pH & EC & $\begin{array}{l}\text { Alkalinity } \\
(\mathrm{mg} / \mathrm{l})\end{array}$ & DO (mg/l) & $\begin{array}{l}\text { Water } \\
\text { phosphate (mg/l) }\end{array}$ & $\begin{array}{l}\text { Water Nitrate } \\
(\mathrm{mg} / \mathrm{l})\end{array}$ & $\begin{array}{l}\text { Soil phosphate } \\
\text { (mg/kg) }\end{array}$ & $\begin{array}{l}\text { Soil nitrate } \\
(\mathrm{mg} / \mathrm{kg})\end{array}$ \\
\hline June & 28.30 & 27.50 & 6.44 & 450.00 & 1.95 & 4.60 & 8.21 & 14.54 & 8.80 & 14.55 \\
\hline July & 28.50 & 27.50 & 6.32 & 485.00 & 1.97 & 5.05 & 8.34 & 14.54 & 9.12 & 14.67 \\
\hline August & 28.70 & 26.85 & 6.71 & 502.50 & 1.95 & 5.83 & 8.39 & 14.54 & 8.95 & 14.81 \\
\hline September & 28.45 & 25.50 & 6.98 & 511.00 & 2.20 & 7.56 & 8.49 & 14.58 & 8.94 & 14.65 \\
\hline October & 28.75 & 27.00 & 7.02 & 531.00 & 2.46 & 7.16 & 8.44 & 14.45 & 9.00 & 14.79 \\
\hline November & 29.00 & 27.25 & 7.03 & 517.50 & 2.80 & 6.74 & 8.46 & 14.54 & 9.08 & 14.78 \\
\hline
\end{tabular}

Key: Air temp- Air temperature, Water temp- water temperature, EC- Electrical conductivity, DO- Dissolve oxygen

Table 4: Selected national and international water quality standard.

\begin{tabular}{|c|c|c|c|c|c|c|c|}
\hline \multirow[t]{2}{*}{ Parameter } & \multicolumn{7}{|c|}{ Maximum permissible limits in water } \\
\hline & NAFDAC & SON & FEPA & NSDW & WHO & $\mathbf{E U}$ & USEPA \\
\hline Conductivity $(\mu \mathrm{s} / \mathrm{cm})$ & 1000 & 1000 & 70 & 1000 & & & \\
\hline Total dissolved solids (mg/l) & 500 & 500 & 500 & 500 & 1000 & & 500 \\
\hline $\mathrm{pH}$ & $6.5-8.5$ & $6.5-8.5$ & $6.0-9.0$ & $6.5-8.5$ & 6.8 & $6.5-9.5$ & $6.5-8.5$ \\
\hline Total hardness & 100 & 100 & & 150 & 100 & & \\
\hline Total alkalinity $\quad(\mathrm{mg} / \mathrm{l})$ & 100 & 100 & & & 100 & & \\
\hline Nitrate (mg/l) & 10 & 10 & 20 & 50 & 50 & 50 & 10 \\
\hline Water temperature $\quad\left({ }^{\circ} \mathrm{C}\right)$ & & & 26 & & 40 & & \\
\hline Dissolved oxygen $\quad(\mathrm{mg} / \mathrm{l})$ & & & $\geq 4$ & & $\geq 6$ & & \\
\hline
\end{tabular}

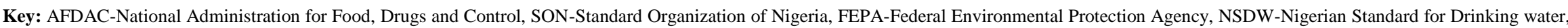
USEPA-United States Environmental Protection Agency, EU-European Union and WHO-World Health Organization. Source: Oketola et al. (2006). 
Table 5: Linear correlation coefficient of the parameters.

\begin{tabular}{|c|c|c|c|c|c|c|c|c|c|c|}
\hline & $\begin{array}{l}\text { Air Temp } \\
\left({ }^{\circ} \mathrm{C}\right)\end{array}$ & $\begin{array}{l}\text { Water } \\
\text { Temp }\left({ }^{\circ} \mathrm{C}\right)\end{array}$ & pH & $\begin{array}{l}\text { EC } \\
(\mu \mathrm{s} / \mathrm{cm})\end{array}$ & Alkalinity & DO (mg/l) & Phosphate (mg/l) & $\begin{array}{l}\text { Nitrate(m } \\
\text { g/l) }\end{array}$ & $\begin{array}{l}\text { Soil Phosphate } \\
(\mathrm{mg} / \mathrm{kg})\end{array}$ & $\begin{array}{l}\text { Soil Nitrate } \\
(\mathrm{mg} / \mathrm{kg})\end{array}$ \\
\hline Air Temp $\left({ }^{\circ} \mathrm{C}\right)$ & 1 & & & & & & & & & \\
\hline Water Temp $\left({ }^{\circ} \mathbf{C}\right)$ & 0.164 & 1 & & & & & & & & \\
\hline pH & -0.032 & -0.083 & 1 & & & & & & & \\
\hline $\mathrm{EC}(\mu \mathrm{s} / \mathrm{cm})$ & -0.018 & $-/ 0.173$ & $0.781 *$ & 1 & & & & & & \\
\hline Alkalinity & 0.252 & 0.383 & 0.516 & 0.459 & 1 & & & & & \\
\hline DO (mg/l) & 0.066 & -0.333 & $0.728^{*}$ & 0.686 & 0.458 & 1 & & & & \\
\hline Phosphate (mg/l) & 0.087 & 0.147 & -0.502 & -0.349 & 0.233 & -0.107 & 1 & & & \\
\hline Nitrate(mg/l) & 0.101 & 0.125 & -0.647 & -0.464 & 0.094 & -0.264 & $0.975^{*}$ & 1 & & \\
\hline Soil Phosphate & 0.118 & 0.230 & -0.454 & -0.314 & 0.337 & -0.145 & $0.967 *$ & $0.948^{*}$ & 1 & \\
\hline Soil Nitrate & 0.112 & 0.121 & -0.675 & -0.470 & 0.063 & -0.283 & $0.963^{*}$ & $0.997 *$ & $0.933^{*}$ & 1 \\
\hline
\end{tabular}

*correlation is significant at 1 


\section{DISCUSSION}

Increase observed in phosphate and nitrate levels both in water and sediment during the sampling period could be due to discharge and sedimentation of suspended particulates from phosphate and nitrogen fertilizers and from domestic waste into the river which was aided by rainfall in these months, thereby increasing the phosphate and nitrate content in the sediment. This is due to anthropogenic activities, associated mainly with urban migration and industrialization, which have resulted to increasing pollution of water bodies (Ayoola and Ajani, 2009).

Normal levels of these minerals though pose no threat to fish survival and performance; high levels can create conditions that can make fish survival impossible. According to Davidson et al. (2014), high levels of nitrates in fish aquaria resulted to prevalence of side swimming, slightly slower growth, decreased survival, and chronic health problems in juvenile rainbow trout. Also, high positive correlation was obtained for $\mathrm{pH}$ level and the levels of electrical conductivity, and dissolved oxygen at these locations.

There are documented evidences that any increase or decrease in $\mathrm{pH}$ outside the recommended limit for fish culture can result to death of the fisheries resources. According to Ikuta et al. (2003) low pH significantly inhibited the reproductive behavior of mature hime salmon Oncorhynchus nerka, brown trout Salmo trutta and Japanese char Salvelinus leucomaenis. Also, ReynalteTataje et al. (2015) reported an almost total mortality of incubated eggs of curimbatá Prochilodus lineatus at $\mathrm{pH}$ 5. Scott et al. (2005) reported a pronounced disruption of ammonia excretion in perch (Perca fluviatilis) exposed to $\mathrm{pH} 9.90$.

Dissolve oxygen, an important parameter for survival of animal life including fish revealed a high positive correlation with the water $\mathrm{pH}$, indicating that any increase in water $\mathrm{pH}$ will mean a corresponding effect in the DO levels of the water. Bagherzadeh Lakani et al. (2013) reported a significant effect on growth rate of Huso huso due to reduction in feed intake and a corresponding changes in stress response accompanied low dissolved oxygen. Low dissolved oxygen value $(2.9 \mathrm{mg} / \mathrm{l})$ recorded in location B (Isabo) for the month of August compared with other months and locations could be attributed to high level of organic decompositions resulting from domestic discharge and industrial effluent. Low and over saturated DO levels was reported to affect growth and food conversion ratio in fish negatively (Mallya, 2007).

Electrical conductivity at these study locations during the study was higher than the permissible limit for fish survival (Oketola et al., 2006). The maximum value was found to be in the month of October which could be due to reduced water volume and the rich nutrient content of the water and corroborated the findings of Ibrahim, Auta and Balogun (2009). The values were within the acceptable limits of (Environmental Protection Agency, 2001; Standard Organization of Nigeria, 2007) standards. Variations in conductivity on a monthly basis at the different locations could be due to types of human activities in the catchment, and to the extent of usage of the water for irrigation.

\section{Conclusion}

It can be concluded that the water from all three locations are still within the recommended reference for fish. Also with exclusion of $\mathrm{pH}$, temperature and $\mathrm{DO}$, other parameters have already exceeded the reference range for fish growth and survival. There is need for constant monitoring of these locations to protect the fisheries resources.

\section{COMPETING INTERESTS}

The author declares that there were no competing interests.

\section{AUTHORS' CONTRIBUTIONS}

AFI designed the study and sample collection and data analysis were by him. He analyzed study results, statistics and interpretation and wrote the draft and final manuscript. 


\section{ACKNOWLEDGEMENTS}

The author appreciates Mr. Adigun and Mr. Joel who assisted him in the collection of sediment.

\section{REFERENCE}

Abdulraheem I, Ojelade OC, Adeosun FI. 2017. The Effect of Refuse on Fish, Water and Sediment of River Sokori, Abeokuta, Ogun State, Nigeria. $J$. Fisheries Livestock Prod., 5(2): 233-236. DOI: $10.4172 / 2332-2608.1000233$

Adejuwon JO, Adelakun MA. 2012. Physiochemical and bacteriological analysis of surface water in Ewekoro Local Government Area of Ogun State, Nigeria: Case study of Lala, Yobo and Agodo Rivers. Int. J. Water Res. Environ. Eng., 4(3): 66-72.

Ayobahan SU, Ezenwa IM, Orogun EE, Uriri JE, Wemimo IJ. 2014. Assessment of Anthropogenic Activities on Water Quality of Benin River. J. App. Sci. Environ. Management, 18(4): 629 636. http://dx.doi.org/10.4314/jasem.v18i4.11

Ayoola SO, Ajani EK. 2009. Seasonal variation in fish distribution and physico-chemical parameters of wetland areas in Oyo State, Nigeria. Int. J. Biol. Chem. Sci., 3(1): 107-116.

Bagherzadeh-Lakani F, Sattari M Falahatkar B. 2013. Effect of different oxygen levels on growth performance, stress response and oxygen consumption in two weight groups of great sturgeon Huso huso. Iranian J. Fisheries Sci., 12(3): 533-549.

Chindah AC, Braide AS, Sibeudu OC. 2004. Distribution of hydrocarbons and heavy metals in sediment and a crustacean (shrimps- Penaeus notialis) from the bonny/new Calabar river estuary, Niger Delta. African J. Environ. Assessment Management, $\quad$ 9: $\quad 1-17$. http://www.srcosmos.gr/srcosmos/showp ub.aspx?aa=8856
Chinedu SN, Nwinyi OC, Adetayo YO, Eze VN. 2011. Assessment of water quality in Canaanland, Ota, Southwest Nigeria. Agric. Bio. J. North America, 2(4): 577583.

Davidson J, Good C, Welsh C, Summerfelt ST. 2014. Comparing the effects of high vs. low nitrate on the health, performance, and welfare of juvenile rainbow trout Oncorhynchus mykiss within water recirculating aquaculture systems. Aqua. Eng., 59: 3040.

DOI: https://doi.org/10.1016/j.aquaeng.2014.0 1.003

Emongor V, Kealotswe E, Koorapetse I, Sankwasa S, Keikanetswe S. 2005. Pollution indicator in Gaberone industrial effluent. J. App. Sci., 5(1): 147-150.

DOI: 10.3923/jas.2005.147.150

Environmental Protection Agency. 2001. Parameters of Water Quality: Interpretation and Standards. Wexford, Ireland.

Ibrahim U, Auta J, Balogun JK. 2009. An assessment of the physico-chemical parameters of kontangora reservoir, Niger state. Bayero J. Pure App. Sci., 2(1): 64-69. DOI: http://dx.doi.org/10.4314/bajopas.v2i1.5 8462.

Ikuta K, Suzuki Y, Kitamura S. 2003. Effects of low $\mathrm{pH}$ on the reproductive behaviour of salmonid fishes. Fish Physio. Biochem., 28(1-4): 407-410. https://doi.org/10.1023/B:FISH.000003 0607.75565.74

Isik S, Dogan E, Kalin L, Sasal M, Agiralioglu N. 2008. Effects of anthropogenic activities on the Lower Sakarya River. Catena, 75(2): 172-181.

DOI: https://doi.org/10.1016/j.catena.2008.06. 001.

Mallya YJ. 2007. The effects of dissolved oxygen on fish growth in aquaculture. The United Nations University Fisheries 
Training Programme, Reykjavik, Iceland.

Mcneely RN, Neimanis VP, Dwyer L. 1979. Water quality Sourcebook: a Guide to Water Quality Parameters. Inland Waters Directorate, Water Quality Branch, Ottawa.

Oketola AA, Osibanjo O, Ejelonu BC, Oladimejim YB, Damazio OA. 2006. Water QualityAssessment of River Ogun around the Cattle Market of Isheri, Nigeria. J. App. Sci., 6(3): 511-517. DOI: $10.3923 /$ jas.2006.511.517

Olalekan OI, Oladipupo SO, Habeeb AQ, Oluwaseun AB. 2012. Influence of Human Activities of the Water Quality of Ogun River in Nigeria. Civil Environ. Res., 2(9): 36-48.

Owuor JJ, Owuor PO, Kengara FO, Ofula AVO, Matano A. 2018. Influence of anthropogenic ctivities and seasons on heavy metals in spring water along Amala and Nyangores tributaries of the
Mara River Basin. African J. Environ. Sci. Tech., 12(7): 222-234. DOI: 0.5897/AJEST2015.2020.

Reynalte-Tataje DA, Baldisserotto B, Zaniboni-Filho E. 2015. The effect of water $\mathrm{pH}$ on the incubation and larviculture of Curimbatá Prochilodus lineatus (Valenciennes, 1837). (Characiformes: Prochilodontidae). Neotrop. Ichthyol., 13(1): 179-186. DOI: http://dx.doi.org/10.1590/1982-022420130127

Scott DM, Lucas MC, Wilson RW. 2005. The effect of high $\mathrm{pH}$ on ion balance, nitrogen excretion and behaviour in freshwater fish from an eutrophic lake: A laboratory and field study. Aqua. Toxicol., 73(1): 31-43.

Standard Organization of Nigeria. 2007. Nigerian standard for Drinking Water Quality (NIS 554: 2007). Standard Organization of Nigeria: Lagos. 